\title{
ANALISIS PROFIL PROSES KOGNITIF PEMAHAMAN KONSEP SISWA
}

\author{
Rachma Afifah \\ Program Studi Pendidikan Fisika, Pascasarjana, Universitas Negeri Semarang \\ Email: rachmafifah@gmail.com
}

Diterima: 13 Desember 2018. Disetujui: 18 Mei 2019.

\begin{abstract}
Abstrak
Proses pembelajaran fisika pada umumnya berpusat pada guru dan kurang memberikan peluang pada siswa untuk mengembangkan potensi diri dengan mengeluarkan ide yang dimiliki. Pembelajaran tersebut mengakibatkan pemahaman konsep siswa kurang. Penelitian ini bertujuan untuk mengetahui profil proses kognitif pemahaman konsep siswa pada materi getaran dan gelombang. Pemilihan sample melalui teknik random sampling. Metode pada penelitian adalah metode eksplorasi. Pengumpulan data untuk profil proses kognitif pemahaman konsep melalui tes berupa soal pilihan ganda yang sudah dibuat sesuai aspek profil proses kognitif pemahaman konsep. Hasil analisis profil proses kognitif pemahaman konsep diperoleh presentase interpretasi 53,33\%; mencontohkan 66,67\%; mengklasifikasi 63,33\%; mengeneralisasi 76,67; inferensi 58,89\%; membandingkan 15\%; menjelaskan 41,11\%.
\end{abstract}

Kata Kunci: getaran, gelombang, pemahaman konsep.

\begin{abstract}
The learning process of physics in general still teacher centered and less give chance for students to expand self potential by issuing idea that they owned. Learning have led to understanding the concept of students less. This study aims to determine the profile of cognitive processes understanding students' concepts in matter of vibration and waves. Sample selection through random sampling technique. The method in research is the method of exploration. Data collection for profile of cognitive processes understanding concepts through tests in the form of multiple choice questions that have been made according to the profile aspects of the cognitive process of conceptual understanding. The results of the profile analysis of cognitive processes understanding concepts obtained percentage of an interpretation 53.33\%; exemplifies $66.67 \%$; classify $63.33 \%$; generalize 76.67; inference $58.89 \%$; compare $15 \%$; explain $41.11 \%$.
\end{abstract}

Keywords:vibration, waves, understanding concepts.

\section{PENDAHULUAN}

Masalah yang dihadapi pendidikan

di Indonesia yaitu lemahnya proses pembelajaran. Banyak dari proses pembelajaran hanya berpusat pada guru dan tidak memberi peluang kepada siswa untuk mengembangkan kemampuan berpikirnya. Proses pembelajaran mengarahkan siswa untuk menghafal informasi, 
mengingat dan mengumpulkan informasi yang banyak tanpa dituntut untuk memahami informasi dan mengkaitkannya dengan kehidupan sehari-hari. Akibatnya banyak lulusan yang kaya teori tetapi untuk pemahaman yang mengembangkan potensi diri atau potensi yang ada di lingkungan relatif rendah. Hal tersebut terjadi karena pemahaman konsep yang masih rendah. Padahal konsep-konsep fisika itu banyak diperoleh dari pengamatan dan percobaan yang dialami siswa.

Kajian penelitian mengenai proses pembelajaran yang berkontribusi terhadap pemahaman konsep siswa diantaranya oleh Kumar dan Madhu (2013) mengenai pengaruh model pencapaian konsep pada akuisisi konsep fisika mengungkapkan bahwa ada perbedaan yang signifikan antara Concept Attainment Method (CAM) dan Traditional Method (TM) pada pencapaian siswa dalam memahami konsep-konsep fisika. Selanjutnya penelitian yang dilakukan oleh Sulisworo dan Novitasari (2017) mengenai metode science learning cycle dengan materi Hukum Newton berpengaruh signifikan dengan kontribusi metode pembelajaran untuk pemahaman konsep adalah 29,4\% dan 98,6\% untuk pembelajaran kemandirian siswa. Kemudian penelitian Arista dan Heru (2018) mengenai penerapan aplikasi laboratorium fisika virtual berbasis android untuk meningkatkan kemandirian belajar dan pemahaman konsep diperoleh hasil aspek pemahaman konsep yang memiliki skor tertinggi adalah pada aspek translation dengan gain 0,72. Baybars dan Huseyin (2018) menyatakan bahwa model pembelajaran 7E efektif dalam pemahaman konseptual calon guru fisika pada materi gelombang de Broglie.

Menurut Hamalik (2008), ada empat hal untuk mengetahui apakah siswa telah mengetahui suatu konsep yaitu: (1) siswa dapat menyebutkan contoh-contoh konsep; (2) siswa dapat menyatakan ciri-ciri konsep tersebut; (3) siswa dapat membedakan antara contoh-contoh dan bukan contoh; dan (4) siswa mampu memecahakan masalah yang berkenaan dengan konsep yang telah dipelajari. 
Ada beberapa kajian mengenai tes pemahaman konsep, seperti yang diungkapkan oleh Akarsu (2011) mengenai Test of Understanding on Concepts of Modern Physics (TUCO$M P)$ untuk mengukur pemahaman konsep siswa pada materi fisika modern dan diperoleh nilai rata-rata tes $41 \%$ siswa mengalami peningkatan. Kemudian Akarsu (2012) juga membuat Test of Conceptual Understanding on High School Optics Topics (TOCUSO) diperoleh hasil bahwa tes dapat digunakan untuk mengukur pemahaman konsep dengan nilai KR20 sebesar 0,73 .

Terkait profil proses kognitif pemahaman konsep diantaranya oleh Basyari(2015) mengenai penerapan levels of inquiry pada tingkat interactive demonstration untuk meningkatkan pemahaman konsep pesawat sederhana siswa SMP disimpulkan bahwa indikator pemahaman konsep yang masuk dalam kriteria kuat peningkatannya yaitu mengklasifikasikan. Kemudian Cahyati(2015) mengenai penerapan model pembelajaran problem solving untuk meningkatkan pemahaman konsep siswa pada materi energi disimpulkan bahwa indikator pemahaman konsep memiliki nilai $\mathrm{N}$ gain paling tinggi yaitu mengklasifikasikan dengan nilai 0,7.

Tujuan dari penelitian ini adalah untuk mengetahui profil proses kognitif pemahaman konsep siswa.

\section{METODE}

Penelitian ini dilaksanakan disalah satu SMK Negeri di Semarang dan dilaksanakan pada semester ganjil tahun ajaran 2018/2019. Sampel ditentukan menggunakan teknik random sampling. Jumlah sampel dalam penelitian ini adalah 30 orang. Metode pada penelitian adalah metode eksplorasi. Materi yang digunakan untuk tes adalah getaran dan gelombang. Pengumpulan data untuk profil proses kognitif pemahaman konsep melalui tes 20 soal pilihan ganda yang sudah dibuat sesuai indikator profil proses kognitif pemahaman konsep. Profil proses kognitif pemahaman konsep menurut Anderson dan Krathwonl (2001) yang dianalisis ditunjukkan pada Tabel 1. 
Tabel 1. Profil Proses Kognitif Pemahaman Konsep

\begin{tabular}{|c|c|}
\hline Profil Kognitif & Definisi \\
\hline 1. Interpretasi & Mengubah dari bentuk yang satu ke bentuk yang lain . \\
\hline 2. Mencontohkan & $\begin{array}{l}\text { Menemukan contoh khusus atau ilustrasi dari suatu konsep atau } \\
\text { prinsip. }\end{array}$ \\
\hline 3. Mengklasifikasi & Menentukan sesuatu yang dimiliki oleh suatu kategori. \\
\hline 4. Mengeneralisasi & Pengabstrakan tema-tema umum atau poin-poin utama. \\
\hline 5. Inferensi & Penggambaran kesimpulan logis dari informasi yang disajikan. \\
\hline 6. Membandingkan & Mencari hubungan antara dua ide, objek atau hal-hal serupa. \\
\hline 7. Menjelaskan & Mengkontruksi model sebab akibat dari suatu sistem \\
\hline
\end{tabular}

\section{HASIL DAN PEMBAHASAN}

Analisis pemahaman konsep ini dilakukan untuk mengetahui indikator mana yang paling menonjol. Dengan membandingkan antara jumlah siswa yang menjawab benar pada setiap indikator dengan jumlah maksimal siswa yang menjawab benar setiap indikator. Hasil analisis indikator memperlihatkan perbedaan pemahaman konsep yang dapat dilihat pada Tabel 2.

Tabel 2. Hasil Analisis Indikator Pemahaman Konsep

\begin{tabular}{llllllll}
\hline Indikator & $\begin{array}{l}\text { Interpre- } \\
\text { tasi }\end{array}$ & $\begin{array}{l}\text { Mencon- } \\
\text { tohkan }\end{array}$ & $\begin{array}{l}\text { Mengklasi } \\
\text {-fikasi }\end{array}$ & $\begin{array}{l}\text { Mengge- } \\
\text { neralisasi }\end{array}$ & Inferensi & $\begin{array}{l}\text { Memban- } \\
\text { dingkan }\end{array}$ & $\begin{array}{l}\text { Menje- } \\
\text { laskan }\end{array}$ \\
\hline Presentase & $53,33 \%$ & $66,67 \%$ & $63,33 \%$ & $76,67 \%$ & $58,89 \%$ & $15,00 \%$ & $41,11 \%$ \\
\hline
\end{tabular}

Profil proses kognitif pemahaman konsep siswa diukur dengan menggunakan instrumen tertulis yang berbentuk soal pilihan ganda yang berjumlah 20 butir soal. Indikator pemahaman konsep yang digunakan sebagai acuan adalah indikator pemahaman konsep menurut taksonomi Anderson yaitu interpretasi, mencontohkan, mengklasifikasikan, mengeneralisasikan, inferensi, mem- bandingkan, dan menjelaskan. Jumlah soal pada tiap indikator berbeda-beda untuk indikator interpretasi 3 butir soal, mencontohkan 3 butir soal, mengklasifikasi 3 butir soal, mengeneralisasi 3 butir soal, inferensi 3 butir soal, membandingkan 2 butir soal, menjelaskan 3 butir soal. Berikut akan dijabarkan proporsi profil proses kognitif pemahaman konsep: 
Kemampuan pertama adalah konsep atau prinsip. Indikator soal kemampuan interpretasi yang berarti mencontohkan yang digunakan dalam kemampuan seseorang mengubah intrumen tes adalah mencontohkan informasi dari bentuk satu ke bentuk lain. Indikator soal interpretasi yang digunakan dalam intrumen tes meliputi menafsirkan, menerjemahkan, dan memformulasikan. peristiwa getaran dan gelombang. Hasil analisis profil proses kognitif pada indikator mencontohkan diperoleh presentase $66,67 \%$.

Contoh kemampuan pada indikator Hasil analisis profil proses kognitif pada indikator interpretasi diperoleh presentase $53,33 \%$.

Contoh kemampuan interpretasi misalnya pada nomor 1, siswa disediakan informasi visual berupa gambar gelombang, kemudian siswa tersebut mendefinisikan informasi dalam bentuk verbal. Indikator interpretasi pada indikator soal memformulasikan hanya ada 1 siswa yang menjawab benar. Hal tersebut dikarenakan siswa masih kesulitan mengubah informasi verbal menjadi informasi yang berbentuk matematis. Siswa kadang juga tidak memperhatikan satuan yang digunakan, sehingga salah dalam memformulasikan persamaan.

Kemampuan yang kedua adalah mencontohkan (exemplifying), yaitu kemampuan seseorang memberikan contoh khusus atau ilustrasi dari suatu mencontohkan yaitu pada soal nomor 14, dimana siswa masih kesulitan dalam memberikan contoh mengenai gelombang longitudinal dibuktikan dengan siswa yang mampu menjawab benar sebanyak 8 siswa.

Kemampuan ketiga adalah mengklasifikasi (classifying), yaitu kemampuan seseorang menentukan sesuatu yang dimiliki oleh suatu kategori. Indikator soal mengklasifikasi yang digunakan dalam intrumen tes meliputi menentukan dan mengkatagorikan. Hasil analisis profil proses kognitif pada indikator mengklasifikasi diperoleh presentase $63,33 \%$.

Contoh kemampuan mengklasifikasi misalnya mengelompokkan suatu peristiwa yang terjadi dalam kehidupan sehari-hari. Misalnya soal nomor 10, siswa diberi peristiwa gelombang yang terjadi 
pada permukaan air tenang ketika di lempar batu. Pada soal ini banyak siswa yang menjawab benar sebanyak 22 orang, tetapi pada indikator yang sama pada soal nomor 17 hanya 5 siswa yang menjawab benar. Hal tersebut dikarenakan masih banyak orang yang masih asing dengan kata metalurgi, sehingga siswa masih kesulitan dalam mengklasifikasikan pemanfaatan gelombang pada bidang metalurgi.

Kemampuan keempat adalah menggeneralisasi (summarizing), hal ini terkait dengan kemampuan seseorang mengasbtrakan tema-tema umum atau poin-poin utama. Indikator soal mengeneralisasi yang digunakan dalam intrumen tes meliputi menentukan dan mengatagorikan. Hasil analisis profil proses kognitif pada indikator mengeneralisasi diperoleh presentase $76,67 \%$.

Contoh kemampuan menggeneralisasi soal nomor 4 siswa disuruh menentukan periode dan hasilnya sekitar 14 siswa dimana yang belum dapat membedakan antara periode dan frekuensi. Kemampuan profil proses kognitif pemahaman konsep presentase paling tinggi pada indikator mengeneralisasi. Hal tersebut senada dengan penelitian yang dilakukan oleh Trianggono (2017) bahwa peningkatan indikator pemahaman konsep pada indikator mengeneralisasi dinyatakan dengan $N$-gain 0,80 .

Kemampuan kelima adalah inferensi yaitu kemampuan seseorang menggambarkan kesimpulan logis dari informasi yang disajikan. Indikator soal inferensi yang digunakan dalam intrumen tes adalah menyimpulkan. Hasil analisis profil proses kognitif pada indikator inferensi diperoleh presentase $58,89 \%$.

Contoh kemampuan inferensi misalnya pada soal nomor 6 dimana siswa diberi beberapa informasi untuk menyimpulkan jawaban yang paling tepat. Siswa yang menjawab benar hanya 6 orang, hal tersebut karena siswa kurang memahami dan teliti terhadap informasi yang ada sehingga kurang tepat dalam menyimpulkan.

Kemapuan keenam adalah membandingkan (comparing), yang berarti kemampuan seseorang mencari hubungan antara dua ide, 
objek atau hal-hal serupa. Indikator soal membandingkan yang digunakan dalam intrumen tes adalah membandingkan. Hasil analisis profil proses kognitif pada indikator membandingkan diperoleh presentase $15 \%$.

Contoh kemampuan membandingkan soal nomor 7 mengenai taraf intensitas bunyi sebuah motor dibandingkan dengan 100 motor yang identik. Siswa masih kesulitan dalam menentukan penggunaan rumus untuk menghitung.Kemampuan profil proses kognitif pemahaman konsep presentase paling rendah pada indikator membandingkan. Rendahnya presentase pada indikator membandingkan diduga karena masih banyak siswa yang tidak dapat menemukan perbedaan antara dua buah objek atau tidak dapat menemukan keterkaitan antara dua objek pada keadaan yang lain.

Hal senada diungkapkan oleh Sari (2016), mengenai strategi PDEODE dalam remidiasi pemahaman konsep mengalami peningkatan paling sedikit $25 \%$ pada indikator membandingkan. Hal tersebut dikarenakan indikator membandingkan tidak terlatihkan secara baik saat proses pembelajaran, kemampuan siswa dalam mengoperasikan perhitungan masih kurang, dan kemampuan elaborasi siswa yang kurang.

Kemampuan ketujuh adalah kemampuan menjelaskan yang merupakan kemampuan seseorang mengkonstruksi model sebab akibat dari suatu sistem. Indikator soal menjelaskan yang digunakan dalam intrumen tes adalah mengkonstruksi. Hasil analisis profil proses kognitif pada indikator menjelaskan diperoleh presentase $41,11 \%$.

Contoh kemampuan menjelaskan soal nomor 15 mengenai kecepatan sumber bunyi yang menjahui pendengar yang diam, hanya 4 siswa yang menjawab benar. Hal tersebut dikarenakan banyak siswa yang masih bingung dengan penggunaan tanda plus dan minus dalam rumus.

Pada indikator menjelaskan dan membandingkan presentasenya lebih rendah. Hal tersebut sesuai dengan penelitian yang dilakukan oleh Cahyati (2015) mengenai Penerapan Model Pembelajaran Problem Solvingdisimpulkan bahwa indikator pemahaman konsep yang nilai $\mathrm{N}$-gain 
Afifah-Analisis Profil Proses Kognitif ...

paling rendah yaitu membandingkan dan menjelaskan dengan nilai 0,3.

Lemahnya kemampuan siswa pada indikator menjelaskan dan membandingkan dapat diatasi dengan mengubah metode pembelajaran. Menurut Kola (2017), metode pembelajaran ceramah interaktif dapat membantu guru dalam mengidentifikasi miskonsepsi dan membantu pembelajaran kolaboratif. Efek ini nantinya akan berdampak pada keterlibatan siswa yang lebih aktif dalam pembelajaran di kelas.

\section{KESIMPULAN DAN SARAN}

Berdasarkan hasil penelitian dan pembahasan dapat diambil simpulan bahwa profil proses kognitif pemahaman konsep diperoleh presentase paling tinggi pada indikator mengeneralisasi 76,67\% dan indikator dengan presentase paling rendah indikator membandingkan $15 \%$.

Berdasarkan hasil tersebut, maka disarankan pada saat proses pembelajaran perlu adanya latihan soal yang melatihkan indikator profil kognitif pemahaman konsep secara menyeluruh dan merata, sehingga siswa terbiasa dengan soal yang melatihkan indikator profil kognitif pemahaman konsep.

\section{DAFTAR PUSTAKA}

Akarsu, B. (2011). Evaluating College Students' Conceptual Knowledge of Modern Physics: Test of Understanding on Concepts of Modern Physics (TUCO_MP). European Journal of Physics Education,2(1),1-7.

Akarsu, B. (2012). TOCUSO: Test of Conceptual Understanding on High School Optics Topics. European Journal of Physics Education,special: 53-59.

Anderson, L. W.,\& Krathwonl, David R. (2001). Taxonomy for learning, Teaching and Assessing: a Revision of Blom's Taxonomy. New York: Longman Publishing.

Arista, F. S., \& Heru K. (2018). Virtual Physics Laboratory Application Based on the Android Smartphone to Improve Learning Independence and Conceptual Understanding. International Journal of Instruction, 11(1), 116.

Basyari, N. (2015). Penerapan Levels of Inquiry pada Tingkat Interactive Demonstrasion untuk Meningkatkan Pemahaman Konsep Pesawat Sederhana pada Siswa SMP. Skripsi tidak diterbitkan Bandung : Universitas Pendidikan Indonesia.

Baybars, M. G.,\& Huseyin K. (2018). The Effect 7E Learning Model on Conceptual Understandings of Prospective Science Teachers on "de Broglie Matter Waves" Subject. European 
Journal of Educational Research, 7(2),387-395.

Cahyati, C. (2015). Penerapan Model Pembelajaran Problem Solving untuk Meningkatkan Pemahaman Konsep Siswa pada Materi Energi. Skripsitidak diterbitkan Bandung :Universitas Pendidikan Indonesia.

Hamalik, O. (2008). Perencanaan Pengajaran Berdasarkan Pendekatan Sistem. Jakarta: PT Bumi Aksara.

Kola, A J. (2017). Investigating the Conceptual Understanding of Physics through an Interactive Lecture-Engagement. Cumhuriyet International Journal of Education, 6(1),82-96.

Kumar, A.,\& Madhu, M. (2013). Effect of Concept Attaiment Model on Acquisition of Physics Concepts. Universal Journal of
Educational Research, 1(3),165169.

Sari, E, R. (2016). Remidiasi Pemahaman Konsep Siswa pada Materi Suhu dan Kalor Menggunakan Strategi PDEODE di SMA. Skripsi tidak diterbitkan Pontianak: Universitas Tanjungpura.

Sulisworo, D., \& Novitasari, S. (2017). Science Learning Cycle Method to Enchance the Conceptual Understanding and the Learning Independence in Physics Learning. International Journal of Evaluation and Research in Education, 6(1), 64-70.

Trianggono, M, M. (2017). Analisis Kausalitas Pemahaman Konsep dengan Kemampuan Berpikir Kreatif Siswa pada Pemecahan Masalah Fisika. Jurnal Pendidikan Fisika dan Keilmuan, 3(1),1-12. 